\title{
The Influence of the Application of Marketing Mix on the Purchase Decision of Prospective Consumers of Grand Cempaka Housing
}

\section{Gesang Sudrajad and J.E Sutanto}

Master of Management, Faculty of Management and Business, Universitas Ciputra, Surabaya, Indonesia

\begin{abstract}
The purpose of this study was to examine the effect of simultaneous and partial marketing mix on the purchasedecision of prospective consumers of Grand Cempaka Housing.This research uses quantitative methods, and is a survey research from the types of explanatory research whose focus is placed on relational research: studying the relationship of variables. The object of research is the residents of Pasuruan City and the sample in this study is the Prospective Consumer of Grand Cempaka Housing. Data analysis uses multiple linear regression analysis methods. The results of the analysis show that Products, Prices, Places and Promotions simultaneously have a significant effect on the Decision of Purchasing Prospective Consumers of Grand Cempaka Housing. This shows that the marketing mix is one of the marketing strategies that should be considered so that the implementation of the marketing strategy can run successfully because the elements in the marketing mix influence each other. Variables in the marketing mix which include Products, Prices, Places and Promotions partially have a significant effect on the Decision of Purchasing Prospective Consumers of Grand Cempaka Housing.
\end{abstract}

Corresponding Author: Gesang Sudrajad gesangsudrajad@gmail.com

Received: 30 December 2019 Accepted: 29 January 2020 Published: 6 February 2020 Publishing services provided by Knowledge E

(c) Gesang Sudrajad and J.E Sutanto. This article is distributed under the terms of the Creative Commons Attribution License, which permits unrestricted use and redistribution provided that the original author and source are credited.

Selection and Peer-review under the responsibility of the 6 th ICOEN 2019 Conference Committee.

\section{G OPEN ACCESS}

Keywords: marketing mix, purchase decision, property, housing

\section{Introduction}

At present, the development trend of the property sector is increasingly crowded with the rise of housing developments, shop houses, malls and apartments in many places. Amid the ups and downs of the property sector dynamics, while some developers face it with optimism and a number of strategies, other developers implements the strategy of reaching the new middle to lower segment of the market, from previously working on the upper middle market. The presence of the property sector will be related to other business sectors. The presence of the property sector related to other industrial sectors has caused the property sector to not be underestimated. Therefore, in order for conditions to remain conducive to the property sector, the momentum needs to be 
maintained in order to contribute to developing other industrial sectors, both directly and indirectly.

Pasuruan City is right on the main route of transportation and trade between Surabaya and Bali, making the City with an area of $36.58 \mathrm{~km} 2$ or around 0.07 percent of East Java's area strategic enough to contribute to the movement of industry and trade. The Pasuruan City Government opens opportunities for cooperation for investors who will invest in Pasuruan City and will help facilitate the ease of the licensing process.

There are many reasons why the property sector business is an option for investors, one of which is because this business is a relatively long-term immovable property business, except when there are calamities or other unwanted events. Grand Cempaka Housing itself is one of the new housing projects developed by PT. Bina Harjo Utomo (BHU). Around 2003, sales of housing in both Taman Asri Housing and Cempaka Housing began to stagnate. Thus since 2015, BHU wants to re-exist as a leading developer in the midst of changing conditions in Pasuruan city. BHU then transformed into Binaland by changing its logo, improving the design of promotions and home architect design to further enhance the quality of the company. Binaland is now also trying to become a housing developer for the upper middle class through its new project called Grand Cempaka. All changes made aim to enable Binaland to compete in Pasuruan City.

To be a successful and accepted developer, an appropriate marketing strategy is needed. An effective marketing program combines all elements of the marketing mix into an integrated marketing program designed to achieve the company's marketing goals by delivering value to consumers. The marketing mix is a tactical mean for the company to determine a strong positioning in the target market. The company does not only focus on what and how a product can be sold to get the highest profits, but now the company must also be able to hear and analyze what matters to consumers before they decide to make a purchase.

In residential products, buying a home for consumers is a very complex decisionmaking activity. In the process of making a home purchase decision, consumers often need a relatively long time. One of the main considerations in making this decision includes the elements contained in the marketing mix. Building quality, price, location and payment system factors are factors that will be considered by consumers in the purchase decision process.

Based on existing theories and problems, the hypotheses in this study are as follows: 
$\mathrm{H1}$ : The application of the marketing mix consisting of: products, prices, places and promotions simultaneously have a positive effect on the purchase decision of prospective consumers of Grand Cempaka housing.

$\mathrm{H} 2$ : The application of the marketing mix consisting of: products, prices, places and promotions partially have a positive effect on the purchasedecision of prospective consumers of Grand Cempaka housing.

\section{Method}

\subsection{Research Design}

This type of this research is survey research of explanatory research, the emphasis being placed on relational research,which is studying the relationship of variables. This study was conducted to obtain data that shows an overview of the influence of variables in the marketing mix which includes products, prices, places and promotions on purchase decision of prospective consumers of Grand Cempaka housing. This research was conducted in Pasuruan City. The choice of study location is based on the consideration that the location allows to obtain data or information that is accurate and relevant to the research problems.

\subsection{Population and Sample}

According to Bungin (2013: 141), the notion of diverse population makes it when viewed from data source divided into two types, i.e. (1) finite population and (2) infinite population. The population is said finite when it has a clear number quantitatively, while it is said infinite if the boundaries cannot be measured quantitatively. The population in this study is the residents of East Java Provine (Pasuruan City and outside Pasuruan City). As for the determination and number of sample developed by Roscoe in Sugiyono (2014: 102), the sample size for the research was between 30-500 people. If the sample is based on category, such as man-woman, cities-villages, then the number of members in each category is at least 30 people. In multivariate research (include multiple regression analysis), the sample size should be 10x larger than the number of variables in the study. For the simple experimental research with a strict experimental control, the successful research is the research with a small sample size, between 10 and 20. Based on Roscoe's advice, the researcher determined the number of samples in the following way:

$\mathrm{n}=$ Total variables $\times(10$ or more), (where $\mathrm{n}=30-500)$ 


$$
\begin{aligned}
& =5 \times 10 \\
& =50
\end{aligned}
$$

Thus, the number of samples taken in this study was 50 respondents. The sampling technique used is non probability sampling, which is random sampling. The part of the non probability sampling technique used is purposive sampling. Based on the procedure of the sampling technique used in this study, the respondents were prospective consumers of Grand Cempaka housing aged between 25-50 years.

\subsection{Data Collection Technique}

Jhonson (2015: 126) states that data collection technique is interpreted as a technique to get data physically to be analyzed in a research study. In this study, the data collection techniques used was questionnaires and interviews. Questionnaire is data collection technique by giving or distributing the list of questions or written statements to the respondents to obtain information about the variables influence on purchase decision of prospective consumers of Grand Cempaka Housing. In the interviews the researcher should be faced with the respondents directly to get depth information and it is an alternative from the limited number of respondents. This data collection techniques are accordance with the opinion by Sekaran (2016: 60) that the primary data refers to the information obtained from the first hand by researcher relating to variables for specific purpose of the study. Interviews were conducted to obtain information on the issues under study and questionnaires were used to obtain relevant data in accordance with the research objectives. In this study, the research instrument uses a Likert scale. The measurement scale used is Very agree, given a score of 5; Agree, given a score of 4; Quite agree, given a score of 3; Disagree, given a score of 2; and Very disagreee, given a score of 1.

\subsection{Analysis Method}

Validity test is conducted using product moment correlation method from Pearson where the testing is done by looking at the correlation coefficient number (rxy) which states the relationship between item score statement with total score (total correlation item). Reliability testing uses the internal consistency method using the Cronbach's Alpha technique.

The formula for multiple linear regression is as follows:

$$
Y^{\prime}=a+b 1 X 1+b 2 \times 2+b 3 \times 3+b 4 X 4
$$


In this study the normality test uses the One Sample Kolmogorov Smirnov Test using a significance level of 0.05 . Then, to test the presence or absence of heteroscedasticity problems is done by looking at whether there is a certain pattern on the scatterplot between SRESID and ZPRED where the $Y$ axis is a residual and the $X$ axis is $X$ that has been predicted. For the autocorrelation test this study uses the Durbin Watson test analysis method (DW test). The regression linearity test is used as a prerequisite in correlation analysis or linear regression. In the testing, SPS is used to do the Test for Linearity with a significant level of 0.05 . For the multicollinearity test the method chosen is to look at the inflation factor (VIF) and Tolerance values in the regression model.

The ability of the regression line to explain the variation that occurs at $Y$ is shown in the magnitude of the coefficient of determination by the coefficient R2. The magnitude of the determination coefficient ranges from $0<R 2<1$, if the coefficient of determination approaches 1 , it is an indicator showing the stronger influence of changes in variable $X$ on changes in independent variable $\mathrm{Y}$. The hypothesis will be tested using the $\mathrm{F}$ test by comparing the probability value with alpha $5 \%$, while the t test aims to determine the effect of partial independent variables: products, prices, places and promotions on purchase decision of prospective consumers of Grand Cempaka housing.

\section{Results}

Based on the information obtained in the field it can be seen that the majority of respondents in this study were male (35 people or 70\%), while the remaining 15 people or $30 \%$ were female. The majority of respondents in this study had a high school education background (SMA) which amounted to 28 people. For the next sequence, 18 people have a Bachelor's degree (S1) education background. Thirty three respondents were married, while the lowest were widows and widowers respondents with the number of each one respondent. Age factor is one of the factors that need to be considered in providing services to consumers. Every certain age level has behavior that tends to be relatively different.

Based on information obtained from the results of the questionnaires, it can be seen that the majority of respondents have a total of 2 children. The second order is respondents with 1 child. While the lowest number is respondents with 4 children, that is equal to 3 people. Finding out the area where respondents are based is intended to find out where prospective consumers are interested in buying a house in Grand Cempaka Housing. 
TABLE 1: Respondent's characteristics based on age.

\begin{tabular}{|c|c|}
\hline Age (in years) & Frequency \\
\hline $25-30$ & 17 \\
\hline $31-40$ & 27 \\
\hline $41-50$ & 5 \\
\hline 50 & 1 \\
\hline Total & 50 \\
\hline
\end{tabular}

TABLE 2: Respondent's characteristics based on their living area.

\begin{tabular}{l|c|}
\hline Living area & Frequency \\
\hline Pasuruan City & 37 \\
\hline $\begin{array}{l}\text { Outside Pasuruan } \\
\text { City }\end{array}$ & 13 \\
\hline Total & 50 \\
\hline
\end{tabular}

Based on information obtained from the respondents, it shows that the majority of respondents, which is 18 people, inhabit the residence which belongs to their parents or siblings. On the other hand, the other minority which is 4 people lives in a residence that belong to the company where the respondent works. The level of income in this case is the amount of income received by respondents each month. This income is important to measure whether the price displayed is in accordance with the ability of consumers to buy.

TABLE 3: Respondent's characteristics based on their income.

\begin{tabular}{l|c|}
\hline Income & Frequency \\
\hline <Rp.3.000.000 & 16 \\
\hline Rp.3.000.000- Rp.5.000.000 & 26 \\
\hline Rp.5.000.001 - Rp.7.000.000 & 4 \\
Rp.7.000.001 - Rp.10.000.000 & 2 \\
\hline Rp.10.000.000 & 2 \\
\hline Total & 50 \\
\hline
\end{tabular}

Based on the results of the validity test of 30 respondents, each indicator in the variable is declared valid, thus it can be concluded that all of these indicators can be used to measure the research variable. To test reliability, the value of Cronbach alpha for all variables is greater than 0.6. From the provisions mentioned earlier, all variables used for the research are reliable. 
Multiple linear regression analysis functions to analyze the shape and influence of two or more independent variables on one dependent variable. Then a multiple linear regression analysis is carried out between the following variable variables: Product (X1), Price (X2),

Place (X3), and Promotion (X4) on the Purchase Decision (Y). From the results of data analysis it is known that the multiple linear regression model is as follows:

$$
Y=0.718+0.139 X 1+0.221 X 2+0.197 X 3+0.303 X 4
$$

That is, if the price variable increases, the Purchase Decision will increase as well. If the Place variable has increased, the Purchase Decision will also increase. If the Promotion variable has increased, the Purchase Decision will increase as well.

Simultaneous testing is done to show whether all the independent variables consisting of Product (X1), Price (X2), Place (X3), and Promotion (X4) variables have a significant effect simultaneously on the dependent variable of Purchase Decision ( $Y$ ). from the hypothesis testing regression models simultaneously using the $F$ test it can be seen that there is a significant value of 0.000 , meaning smaller than alpha $(\alpha)=0.05$. Therefore, it can be concluded that $\mathrm{HO}$ is rejected and $\mathrm{Ha}$ is accepted, meaning that there is a simultaneous influence between the Product (X1), Price (X2), Place (X3), Promotion (X4) variables on the Purchase Decision variable $(Y)$.

Partial testing of regression models is used to determine whether each of the independent variables forming the regression model individually has a significant influence on the $Y$ variable or not. This test shows that the Product variable (X1) has a significant effect on Purchase Decision variable $(Y)$, Price variable $(X 2)$ has a significant effect on Purchase Decision variable (Y), Place variable (X3) has a significant effect on Purchase Decision variable $(Y)$, and Promotion variable $(X 4)$ has a significant effect on the Purchase Decision variable $(\mathrm{Y})$.

The coefficient value $R$ indicates the closeness of the relationship between the dependent variable and the independent variable. In this study the product (X1), Price (X2), Place (X3), Promotion (X4) variables on the Purchase Decision was found to be 0.879 which indicates a very strong relationship or influence.

\section{Discussion}

From the $F$ test results it was known that together, the Product (X1), Price (X2), Place (X3) and Promotion (X4) variables have a jointly significant effect (simultaneous) on the Prospective Consumer Purchase Decision $(\mathrm{Y})$. This study shows that Purchase Decision 
is strongly influenced by Product, Price, Place and Promotion variables. The magnitude of the contribution of the four variables in influencing the Purchase Decision is $77.2 \%$. The influence of the four independent variables in this study is quite large on the Prospective Consumer Purchase Decision.

The results of this study are in line with research conducted by Algrina (2013) which shows that simultaneously, products, prices, places and promotions have a significant effect on purchase decision. The results of this study are also in line with those carried out by Jilly (2013) regarding the effect of products, prices, places and promotions simultaneously having a significant effect on purchase decision.

Yesi et al. (2014) in the study aimed to determine the factors of marketing mix and considered dominant variables by the consumers in buying products. The dominant variables considered by the consumers are brand variable in product factor, taste variable in aroma and taste factors, arrangement variable in supermarket in place factor, and ad appearance variable in promotion factor. Geraldy (2013) conducted the study on the influence of marketing mix. The study aimed to determine the influence of marketing mix, such as products, prices, places, and promotions, on sales volume. The results of Geraldy's study show that product and price variables significantly influence on sales volume, while place and promotion variable did not significantly influence on sales volume.

The study conducted by Febrianti (2012) on the influence of marketing mix variables on consumers decision shows that simultaneously, there was a significant effect between products, prices, places, promotions, and person on consumers decision. From the five variables, it is only promotion variable do not have significant influence on consumer decision in buying. Rezky (2012) conducted the study to determine the relations between marketing mix (4P) on consumer decision making. The results of the study show that only product and price are most influence on consumer decisions. The study conducted by Florence (2015) in examining the effects of marketing mix using 7 variables, i.e. Product, Price, Place, Promotion, People, Processes dan Physical Evidence. The results of this study show that price, product or service, place, people, process, physical evidence, and promotion are important attribute in purchase decision. Murwatiningsih (2014) examines the direct and indirect effect of marketing mix on purchase decision. The results show that there were direct and indirect effect of empowerment marketing mix consisting of product, price, place, promotion, personal characteristic, and physical appearance variables on consumers purchasing.

Binaland in developing Grand Cempaka Housing needs to pay attention to the products that are sold, namely in the form of houses having specifications according to 
the needs desired by the buyer. Binaland is good enough in building a house whose specifications were in accordance with the customer's wishes. Binaland has also created a home design that fits the current trend. In addition, Binaland owns public facilities like tennis courts, which are one of the main features not owned by other developers. In general, prospective consumers are attracted to housing whose environment has green areas and sports facilities so that it can be used together for the comfort of residential areas.

In terms of price, the houses in Grand Cempaka Housing have a fairly competitive price in accordance with the specifications. In addition, Binaland as the developer also gave gifts and prizes such as kitchen sets for buyers who buythe house during a promo period to make people interested in buying. The prospect of resale prices is also attractive so that people who buy houses not only use the house as a place to live, but also worth the investment.

The strategic and easily accessible location of Grand Cempaka Housing is also an attraction. In front of the housing location, public transportation facilities are easily accessible. The location of housing is built on flat land/not on the edge of the river, thus the security of this location is assured since it is far from disaster vulnerabilities such as landslides.

The promotion carried out by Binaland in marketing its products in the form of Grand Cempaka Housing is also quite good. Promotional media uses media that are easily accessible by the people of Pasuruan City such as through billboards, banners in strategic areas and brochures. This promotion media is important so that indirectly the people will get to know Binaland's products more. Besides, it also makes it easier for the community to get the right information relating to the products sold.

Based on the results of the research conducted, it is known that the Product variable (X1) has a positive and significant effect on the Purchase Decision variable (Y). The product in this study is a house that is sold at Grand Cempaka Housing. In addition to core products, there are also complementary products that can add to the selling value of an item. In addition to maximizing home products to suit consumer's needs, Grand Cempaka Housing also provides mosques and sports facilities including tennis courts and children's playgrounds to increase the attractiveness to the buyers.

Based on the results of the research conducted, it is known that the Price variable $(\mathrm{X} 2)$ has a positive effect on Purchase Decision (Y). The results of the study indicate that one of the major interests of prospective buyers is the price discount and other prizes when the consumer makes a purchase. In addition to price discounts, easy access to payments is also considered important by prospective consumers, such as the existence 
of a Housing Loan facility/mortgage (KPR). The existence of a mortgage will help ease consumers to buy the product.

Based on the results of the research conducted, it is known that the Place variable $(\mathrm{X} 3)$ has a positive effect on Purchase Decision (Y). Judging from the place variable, this study shows that most respondents strongly agree that Grand Cempaka Housing has the advantage of a flood-free housing environment. The location of housing is indeed in a flood-free path with the condition of a flat land contour. Grand Cempaka housing is also in a strategic location that is passed by public transportation facilities. This makes it easier for people to reach out and facilitate day-to-day mobilization.

Based on the results of the research conducted, it is known that the Promotion variable (X4) has a positive effect on Purchase Decision (Y). From the results of the study, it was shown that most respondents said that it was easy to find out about the Grand Cempaka Housing through a signpost. Signposts installed in several strategic locations will make it easier for prospective customers to find out which products are being marketed.

\section{References}

[1] Agnes, Algrina dan Ulus. 2013. Bauran Pemasaran Pengaruhnya Terhadap Keputusan Pembelian Mobil Daihatsu Pada PT. Astra International Manado. ISSN 2303-1174.

[2] Anonim. 2015. Dampak Perkembangan Ekonomi Terhadap Sektor Industri Properti dan Konstruksi di Indonesia, https://viventisblog.wordpress.com. 2 September 2016.

[3] Anonim. 2016. Kota Pasuruan Menghadapi Tantangan Baru, http://www. pasuruankota.go.id. 20 Agustus 2016.

[4] Anonim. 2016. Prospek Bisnis Properti Tahun 2016 di Mata Pengembang, http:// www.properti.kompas.com. 26 Agustus 2016.

[5] Arikunto, S., 2016. Prosedur Penelitian (Suatu Pendekatan Praktek), Edisi Revisi ke-4, Jakarta: PT. Rineka Cipta.

[6] Assuari, Sofyan. 2014. Manajemen Pemasaran: Dasar, Konsep dan Strategi. Jakarta: Raja Grafindo Persada.

[7] Bernadette, Jilly. 2013. Promosi, Distribusi, Harga Pengaruhnya Terhadap Keputusan Pembelian Rokok Surya Promild. ISSN 2303-1174.

[8] Buchari, Alma. 2014. Manajemen Pemasaran dan Pemasaran Jasa. Bandung: Alfabeta Bungin, Burhan. 2013. Metodologi Penelitian Kuantitatif: Komunikasi, 
Ekonomi dan Kebijakan Publik Serta IImu -- IImu Sosial Lainnya. Jakarta: Putra Grafika.

[9] Dharmesta, B.S. dan Handoko. 2012. Manajemen Pemasaran: Analisis Perilaku Konsumen. Yogyakarta: PBFE Universitas Gajahmada.

[10] Febrianti, Fanti. 2012. Pengaruh Variabel Bauran Pemasaran Terhadap Keputusan Konsumen Dalam Membeli Ruko. Malang.

[11] Ferdinand, Augusty. 2016. Metode Penelitian Manajemen. Semarang: Badan Penerbit Universitas Diponegoro.

[12] Geraldy. 2013. Bauran Pemasaran Pengaruhnya Terhadap Penjualan Sepeda Motor Yamaha di PT. Sarana Niaga Megah Kerta Manado. ISSN 2303-1174.

[13] Ghozali, Imam, 2014. Aplikasi Analisis Multivariate Dengan Program SPSS. Semarang: Penerbit Universitas Diponegoro.

[14] Indriantoro dan Supomo, 2012. Metodologi Penelitian Untuk Akutansi dan Manajemen, Cetakan kedua, Yogyakarta: BPFE.

[15] Johnson, B. Dan Christensen, L. 2015. Educational Research 4th Edition: Quantitative, Qualitative and Mix-Methods Approaches. California: SAGE Publication.

[16] Kamau, Florence. 2015. The Effects Of The Marketing Mix On Choice Of Tourist Accomodation by Domestic Tourist In Kenya. International Journal Of Novel Research in Marketing Management and Economics Vol. 2.

[17] Kotler, Philip dan Gary Armstrong. 2014. Prinsip -- Prinsip Pemasaran, Jakarta: Erlangga. Kotler, Philip. 2013. ManajemenPemasaran. Jakarta: Erlangga.

[18] Krista, Yesidkk. 2014. Analisis Respon Konsumen Terhadap Faktor -- Faktor Marketing Mix Dalam Pembelian Produk Luwak White Koffie di Pasar Swalayan Kota Surakarta. Jurnal Agriekonomika, ISSN 2301-9948 Vol.3 No.2.

[19] Lupiyoadi, Hamdani. 2006. Manajemen Pemasaran Jasa. Jakarta: Salemba Empat. Malhotra, N.K., 2016. Marketing Research. London: Prentice Hall International Industri.

[20] Murwatiningsih. 2014. Empowering The Marketing Mix Toward Purchasing Decision Based On Consumer's Character At Traditional Markets in Semarang. International Journal Of Business, Economic and Law Vol.4.

[21] Narimawati, Umi. 2013. Metodologi Penelitian Kualitatif dan Kuantitatif, Teori dan Aplikasi. Bandung: Agung Media.

[22] Nurbaity, ArlinaLubis. 2004. Strategi Pemasaran Dalam Persqaingan Bisnis.

[23] Peter J. Paul dan Olson Jerry C. 2014. Consumer Behaviour and Marketing Strategy. New York: McGraw Hill. 
[24] Purna, Rezky. 2012. The Relationship Between Marketing Mix and Consumer Decision- Making Over Travel Agents: An Empirical Study. International Journal Of Academic Research In Business And Social Sciences Vol.2 No.6.

[25] Schiffman dan Kanuk. 2015. Perilaku Konsumen. Jakarta: Indeks Gramedia Sekaran, Uma. 2016. Metode Penelitian Untuk Bisnis. Jakarta: Salemba Empat.

[26] Singarimbun, Masri dan Sofian Effendi. 2016. Metode Penelitian Survai. Jakarta: LP3ES. Singgih, Santoso. 2016. Statistik Non Parametrik. Jakarta:Elex Media Komputindo.

[27] Sugiyono. 2014. Statistika Untuk Penelitian. Bandung: CV Alfabeta.

[28] Swastha DH dan Irawan. 2013. Manajemen Pemasaran Modern. Yogyakarta: Liberty Offset. 